\title{
A COMPARATIVE INQUIRY INTO THE LEGAL REGIME OF MORTIS CAUSA DONATIONS IN SOME CONTINENTAL-EUROPEAN AND COMMON LAW \\ LEGAL SYSTEMS Codrin CODREA
}

\author{
“Al. I. Cuza" University, Iași, Romania \\ codrin_codrea@yahoo.com
}

\begin{abstract}
The mortis causa donation is a particular form of donation, made in the anticipation of death. Its regime was subjected to particular different norms in some continental-European legal systems, such as the French and the Romanian ones, and in some common law legal systems, such as the English and the American ones. This article investigates in a comparative manner the different legal solutions regarding the status of mortis causa donations in French and Romanian legal systems, on one hand, and in the English and American legal systems, on the other. Although in the history of French law the donation mortis causa was recognized under the customary norms of the ancien droit, contemporary continental-European legal systems do not recognize an intermediary gratuitous act between testamentary provisions and donation contracts, while in the common law legal systems the mortis causa donation is recognized as a particular form of gratuitous transfer, but it has different legal effects in English and American legal systems.
\end{abstract}

Keywords: mortis causa donation, inter vivos donation, French law, English law, American law

\section{Introduction}

The mortis causa donation can be briefly defined as a donation made in the expectance of death. As such, it presupposes both an inter vivos element, since it is concluded during the lives of the parties, and a mortis causa element, since the donor makes the donation while he is in the proximity of death. The inter vivos and mortis causa elements that this kind of donation cumulates posed certain problems for continental-European and common law legal systems. While in the French legal system the mortis causa donation was recognized during the 'ancien droit', after the $18^{\text {th }}$ century legislative reform of Henri-François d'Aguesseau, all liberalities (libéralités) had to respect strict formalities for their validity, implicitly allowing only inter vivos donations and testaments for mortis causa gratuitous transfers. This solution was later adopted by the Napoleonic Code and in all continental- European legal systems that were inspired

by the Napoleonic Civil Code.

The common law, however, did not impose similar restrictive forms for gratuitous transfers, and thus, mortis causa donations are recognized as valid, if made in certain conditions. Therefore, looking in a comparative manner to continentalEuropean and common law legal systems, the solutions adopted in these two legal families are diverging with regard to mortis causa donations. In order to understand the different perspectives on this type of donations, certain historical clarifications are in order for both legal families. 


\section{Mortis causa donations in continental- European legal systems}

Henri-François d'Aguesseau as a chancellor of King Louis the $15^{\text {th }}$ and influenced by Domat, had an ideal of unifying the various French customary laws by imposing an uniform, written, set of laws for the entire French kingdom. In order to achieve the legal unity he elaborated the project of a civil code for which he drafted three ordinances - two of them regarding the testaments and fideicommissary substitutions and in 1731, an ordinance regarding donations [1]. French legal scholarship regards these legislative initiatives as acts of fundamental importance in the civilian legal history, since the ordinances of d'Aguesseau represented a reference point and an inspiration for the later Code Napoleon, adopted in 1804 [2].

The ordinance which had a major impact on the legal regime of mortis causa donations was "L'ordonnance sur les donations". It contains 47 articles and brought a number of legal novelties in the French legal scenery - for example, it stated for the first time the formality requirement for the validity of donations, imposing that all inter vivos donations, under the sanction of nullity, had to be concluded in front of the public notary, respecting the solemn, authentic form ('Article premier: Les donations doivent être faites par actes public, et il en doit refter minute à peine de nullité'). Another novelty consisted in the repeal of mortis causa donations (donations à cause de mort) [3]. Article III of "L'ordonnance sur les donations" states that 'All donations mortis causa, excepting those made through a marriage contract, shall have no effect from now on in the countries where they were concluded respecting their laws or customary norms, unless they were concluded respecting the same form as testaments and codicils. In the future, in our countries there shall be only two forms of gratuitously disposing of property - one of the inter vivos donations and the other one of the testaments and codicils' ('Article III, De lafome des Donations a caufe de mort - Toutes donations a caufe de mort, $\mathrm{d}$ l'exception de celles qui fe feront par Contrat de marriage, ne pourront d'ors en avant avoir aucun effet dans les Pays memes ou ells font expreffement autorifees par les Loix ou par les Coutumes, que lorfqu'elles auront ete faites dans la meme forme que les Teftamens ou les Condiciles: enforte qu'il n'y ait a l'avenir dans nos Etats que deux forms de difpofer de fes biens a titre gratuit, dont l'une fera celle des Donations entrevifs \& l'autre celle des Teftamens ou des Codiciles') [4]. In adition to this explicit provision which restricted all gratuitous transfers only to donations and testaments which were required strict form conditions, article IV states that all inter vivos donations, which are not valid as such, shall not be interpreted neither as a donation, nor as a mortis causa disposition, nor as a testamentary one [5].

Before the Ordinance of d'Aguesseau, in the French 'Ancien Droit', mortis causa donations represented a third type of gratuitous dispositions, besides the regular inter vivos donations and the testamentary dispositions. The prohibition of mortis causa donations targeted a specific hypothesis, common to $18^{\text {th }}$ century France, in which the descendents would dispose of their future property in the benefit of their fathers. The effect of the prohibition was that the fathers would not be able to acquire the property of their descendents without coming to inheritance by testament or, in the case of ab intestate succession, in competition with the mother, brothers and sisters of the deceased [6].

The prohibition of this type of donations was grounded on two justifications which Henri-François d'Aguesseau elaborated. First of all, mortis causa donations could have hardly been assimilated to donations. The main traits of a donation, its fundamental characteristics, are the liberal intent of the donor, the 'animus donandi' and the impoverishment of his patrimony, 
the diminishing of his wealth. Thus, a gratuitous disposition is a donation only when through his own liberal intent the donor would accept the reduction of his wealth. D'Aguesseau reasoning points that although through a mortis causa donation the donor would have suffered indeed a reduction of his wealth with the benefit given to the donee, taking into consideration the circumstances in which such a donation was concluded, the wealth itself wouldn't have remained in the ownership of the donor. The circumstances in which mortis causa donations were made were explicitly stated in the customary laws of the Ancien Droit - for example, article 277 of the Custom of Paris states that a mortis causa donation is a donation made in the last days of the donor on the death bed. In such circumstances, d'Aguesseau argues that the patrimonial effects of the mortis causa donation is irrelevant to the donor, or at least the state of his wealth does not amount to the same importance as it usually does to someone who is not in the proximity of death.

Second of all, d'Aguesseau considered the predisposition of the donor who was in that particular state to be subjected to influences in order to make a mortis causa donation in favour of those who would have manipulated his consent [7].

These two arguments grounded the justification for limiting the gratuitous dispositions only to inter vivos donations and testaments. The classification of gratuitous dispositions made by d'Aguesseau was later adopted in the Code Napoleon, where the donation, like the testamentary gratuitous transfers of property, is a liberality ('libéralité'). Following the French model which considers that donations are liberalities, also in the Romanian Civil Code the provisions governing donations are to be found in the section dedicated to liberalities, alongside testaments, and not together with the other contracts. The contemporary French Civil Code states in article 893 that 'The liberality is an act through which a person disposes gratuitously of his entire or of a part of his property or rights in favour of another person. A liberality can be made only through an inter vivos donation or testament'. Similarly, article 984 of the Romanian Civil Code states that '(1) The liberality is the legal act through which a person gratuitously disposes of his property, entirely or partially, in favour of another person'. The second paragraph of the article states the same restriction that can be found in the French law - that '(2) liberalities can be made only through a donation or through a testamentary disposition', formulation which is almost identical to the one in the article 893 of the Napoleonic Code ('On ne pourra disposer de ses biens, à titre gratuit, que par donation entre-vifs ou par testament, dans les formes ci-après établies').

However, as a revenge of the exclusion of mortis causa donations, in French law a certain institution similar to a mortis causa donation is exceptionally accepted 'institutions contractuelles' (contractual institutions) which is a hybrid gratuitous disposition at the confluence of inter vivios donations and testamentary dispositions. The contractual institution implies that one party institutes another as an inheritor through the means of a contract. This institution has a double exceptional character, since it presupposes an agreement on a future inheritance, generally prohibited in the French law, and also it presupposes a revocable donation, as an exception to the special principle of donations irrevocability. Also, the French Civil Code restricts the area of 'institutions contractuelles' only to the realm of donations in relation to the marriage, made between future spouses before the marriage (article 1082 of the French Civil Code) or by a third party to the future spouses (article 1093 of the French Civil Code), or between spouses during marriage (article 1096 of the French Civil Code).

\section{Mortis causa donations in common law legal systems}

Although the distinction between the inter 
vivos and the mortis causa gratuitous transfers which can be found in continentalEuropean legal systems seems to be grounded on a firm criterion that allows a safe qualification of a certain gratuitous transfer as a donation, in common law there is still recognized the hybrid legal institution of the mortis causa donation, which, combining both inter vivos and mortis causa elements raises questions regarding the strict separation between the two categories of liberalities in the French inspired legal systems.

As shown in the previous section, in the French and Romanian legal systems, the legal solution was to exclude mortis causa donation from the category of inter vivos gratuitous transfers and to assimilate it to testamentary dispositions governed by the inheritance law. As a result to this legal assimilation, the gratuitous dispositions made in the contemplation of death produce their effects after the death of the disposer and are excluded from the irrevocability principle to which all inter vivos donations are subjected.

In common law the legal solution is the opposite - the category of inter vivos donations is extended to cover also those transfers which have legal effects after the death of the donor. Therefore, as an exception from the general rule of donation irrevocability, common to continentalEuropean and common law legal systems, if the gratuitous transfer of a personal property was made in apprehension of imminent death, such a donation is qualified as a mortis causa donation and as such it is considered to be revocable. The donor has the right to revoke the donation in reasonable term after he no longer finds himself under the influence of the fear of imminent death, and only if he chooses not to exert his right, the mortis causa donation becomes irrevocable [8].

In order for a gratuitous transfer to be qualified as a mortis causa donation, certain conditions have to be fulfilled. First of all, the donation has to have as object mobile goods (personal property), second of all, it has to be concluded under the fear of imminent death, third of all, the intent of the donor has to be that the donation produces full effects after his death, and, fourth of all, there has to be a delivery from the donor to the donee [9].

In both English and American laws, a mortis causa donation can have as objects only mobile goods (personal property). In the English law, however, incorporeal mobile goods (choses in action), cannot be the object of a mortis causa donation since they cannot be transferred through delivery. In the American law, initially, it was adopted the same solution as in the English law - there were considered valid only those mortis causa donations which consisted only in corporeal mobile goods (chattels), goods which could have been manually delivered. Later, through a series of decisions, mortis causa donations which consisted in incorporeal mobile goods (choses in actions), which can be transferred through the personal delivery of the title that proofs the ownership over those goods, were also accepted as valid [10].

In the judiciary practice there was an issue regarding the condition of the fear of imminent death. Such a condition is fulfilled, for example, when A is going to be subjected to a serious medical intervention which he reasonably considers to have a fatal potential. In this case, if A makes a donation, it will be a mortis causa donation, subjected to revocability [11].

Regarding the effects of the mortis causa donations, they take place only after the death of the donor. Until the death of the donor, he has the right to unilaterally revoke his donation. However, the donation will not have any effects if the donor is no longer exposed to the danger in contemplation of which he made the mortis causa donation. The donation will have full effects if the death of the donor is due to an unexpected cause, different than the one considered by the donor, but which makes that the donor does not survive the situation in contemplation of which he made the 
mortis causa donation [12].

The effects of the mortis causa donations are not identical in English and American legal systems. In the English law,the ownership is not transferred to the donee until the death of the donor [13]. In the legal terms of the continental-European legal systems, the mortis causa donation in the English law has the nature of a donation under the suspensive condition of the death of the donor, since until the fulfilment of the condition no transfer of ownership takes place.

In the American law, full ownership is transferred to the donee in the moment of the conclusion of the mortis causa donation. In the absence of such a transfer, the act is not a donation, but an invalid gratuitous testamentary transfer. Unlike a testamentary disposition where the disposer keeps the use of the property (beneficial enjoyment) during his life, a mortis causa donation instantly transfers the ownership of the donated good, including the use of the property, under the condition of the death of the donor [14]. A translation into the legal language of the continental-European legal systems of the effects of mortis causa donations in American law would render such a donation as a donation made with the condition subsequent of the donor surviving the anticipated event in the contemplation of which he gratuitously disposed of his property. In the case of such a donation, the transfer of the ownership takes place at the moment of the conclusion of the donation, but it is retroactively dissolved when the event - the survival of the donor - takes place.

Another difference between the mortis causa donation in the English and American legal systems consists in the conditions for a valid delivery - although both in the English and in the American law the delivery has to take place during the life of the donor, what qualifies a delivery as complete differs in the two legal systems [15]. In the English law, where the mortis causa donation appears as an incomplete inter vivos donation, it is necessary that the executor or administrator of the donor does whatever it is needed to complete the donation, while in the American law there are required for the delivery of the property the same conditions as for any inter vivos donation [16].

\section{Conclusions}

The fate of the legal institution of the mortis causa donation is intrinsically linked to the particular evolutions of the continental-European legal systems, generally French-inspired, and of the common law legal systems. Although it was widely used in the French 'Ancien Droit', after the 1731 legislative reforms of HenriFrançois d'Aguesseau, the French law excluded mortis causa donations as a valid type of gratuitous disposition. Following the example of d'Aguesseau, the Napoleonic Code of 1804 also expressed no interest in reviving the mortis causa donations. However, the French systems recognized a form of mortis causa donations through the 'institutions contractuelles' which are accepted only if such dispositions are made in relation to the marriage. In opposition to the solution adopted in the continental-European legal systems, the common law legal systems followed a different path since the mortis causa donations were never subjected to any similar prohibitions and are still accepted, although they have different effects in the English law and the American law.

\section{Acknowledgements}

This work was supported by the strategic grant POSDRU/159/1.5/S/141699, Project ID 141699, co-financed by the European Social Fund within the Sectorial Operational Program Human Resourses Development 2007-

2013. 


\section{References}

[1] Butler Charles, Memoir of the Life of Henry-Francis D'Aguesseau, London, John Murray Albemarle-Street, 1830, pp. 50-56.

[2] Regnault Henri, Capitant Henri, Les ordonnances civiles du Chancelier Daguesseau: Les donations et l'Ordonnance de 1731, Paris, Recueil Sirey, pp. 50-57.

[3] Furgole Jean-Baptiste, Ordonnance de Louis XV, Toulouse, Antoine Birrose, 1761, p. 3.

[4] Furgole Jean-Baptiste, Ordonnance de Louis XV, Toulouse, Antoine Birrose, 1761, p. 18.

[5] Furgole Jean-Baptiste, Ordonnance de Louis XV, Toulouse, Antoine Birrose, 1761, p. 30.

[6] François de Boutaric, Explication de l'Ordonnance de Louis XV, du mois de Février, 1731, concernant les donations, Avignon, François Girard Imprimeur Libraire, 1766, p. 12.

[7] Hyland Richard, Gifts. A Study in Comparative Law, New York, Oxford University Press, 2009, pp. 171-172.

[8] American Law Institute, Restatement of the Law Third, Property, Wills and Other Donative Transfers, Vol. II, Washington D.C., American Law Institute Publishers, 2003, p. 33.

[9] Hyland Richard, Gifts. A Study in Comparative Law, New York, Oxford University Press, 2009, p. 456.

[10] Hyland Richard, Gifts. A Study in Comparative Law, New York, Oxford University Press, 2009, pp. 456-457.

[11] American Law Institute, Restatement of the Law Third, Property, Wills and Other Donative Transfers, Vol. II, Washington D.C., American Law Institute Publishers, 2003, pp. 33-34.

[12] Hyland Richard, Gifts. A Study in Comparative Law, New York, Oxford University Press, 2009, p. 459.

[13] Hyland Richard, Gifts. A Study in Comparative Law, New York, Oxford University Press, 2009, pp. 459-460.

[14] American Law Institute, Restatement of the Law Third, Property, Wills and Other Donative Transfers, Vol. II, Washington D.C., American Law Institute Publishers, 2003, p. 33.

[15] Watkins Thomas Powell, Analysis of American Law, Clark, New Jersey, The Lawbook Exchange Ltd, 2008, p. 238

[16] Hyland Richard, Gifts. A Study in Comparative Law, New York, Oxford University Press, 2009, p. 457. 